\title{
Isotopic composition and origin of polar precipitation in present and glacial climate simulations
}

\author{
By MARTIN WERNER ${ }^{1 * \ddagger}$, MARTIN HEIMANN ${ }^{2}$ and GEORG HOFFMANN ${ }^{3},{ }^{1}$ Max-Planck- \\ Institute for Meteorology, Bundesstr. 55, D-20146 Hamburg, Germany; ${ }^{2}$ Max-Planck-Institute for \\ Biogeochemistry, P.O. Box 100164, D-07701 Jena, Germany; ${ }^{3}$ Laboratoire des Sciences du Climat et de \\ l'Environnement, Centre d'Etudes Orme des Merisiers, F-91191 Gif sur Yvette, France
}

(Manuscript received 26 November 1999; in final form 30 May 2000)

\begin{abstract}
The Hamburg atmospheric general circulation model (AGCM) ECHAM-4 is used to identify the main source regions of precipitation falling on Greenland and Antarctica. Both water isotopes $\mathrm{H}_{2}{ }^{18} \mathrm{O}$ and $\mathrm{HDO}$ are explicitly built into the water cycle of the AGCM, and in addition the capability to trace water from different source regions was added to the model. Present and LGM climate simulations show that water from the most important source regions has an isotopic signature similar to the mean isotope values of the total precipitation amount. But water from other source regions (with very different isotopic signatures) contributes an additional, non-negligible part of the total precipitation amount on both Greenland and Antarctica. Analyses of the temperature-isotope-relations for both polar regions reveal a solely bias of the glacial isotope signal on Greenland, which is caused by a strong change in the seasonal deposition of precipitation originating from nearby polar seas and the northern Atlantic. Although the performed simulations under LGM boundary conditions show a decrease of the $\delta^{18} \mathrm{O}$ values in precipitation in agreement with ice core measurements, the AGCM fails to reproduce the observed simultaneous decrease of the deuterium excess signal.
\end{abstract}

\section{Introduction}

Ice cores form polar regions certainly belong to the most intriguing paleo-archives of climate. Measurements of isotopes, radio-nuclides and chemical impurities in deep ice cores from Greenland and Antarctica have revealed many new details of past climate changes, especially of the last glacial stage and its transition to the Holocene (e.g., Beer et al., 1988; Dansgard et al., 1993; Jouzel et al., 1987, Yang et al., 1997). For a correct interpretation of the variations of such

\footnotetext{
* Corresponding author e-mail: werner@misu.su.se

$\ddagger$ Present affiliation: Department of Meteorology, Stockholm University, S-10691 Stockholm, Sweden.
}

tracers in the ice, the origin of precipitation and the climatic conditions during the formation of precipitation are important information to know.

Measurements of stable water isotopes $\mathrm{H}_{2}{ }^{18} \mathrm{O}$ and HDO in ice cores (expressed as $\delta^{18} \mathrm{O}$ and $\delta$ D) have been used to derive essential information. On its way typically from low latitudes to high latitudes an air parcel undergoes successive condensation processes continuously depleting isotopically the remaining water vapor. In various theoretical studies it has been shown that the isotopic composition of precipitation is mainly controlled by the temperature difference between the evaporation site and the condensation site (Aristarain et al., 1986; Dansgaard, 1964; Jouzel et al., 1997). Given the oceanic source region has not significantly changed the 
$\delta^{18} \mathrm{O}(\delta \mathrm{D})$ signal of polar ice cores therefore reflects local temperature variations. The observed present-day (spatial) relation between $\delta^{18} \mathrm{O}, \delta \mathrm{D}$ and surface temperatures of polar sampling sites (Dahe et al., 1994; Dansgaard, 1964; Johnsen et al., 1989; Lorius et al., 1979) are taken as transfer functions to interpret temporal changes of the $\delta$-values as changes of surface temperatures at the drill site. But new, isotope-independent estimates of past temperatures on the Greenland ice sheet (Jouzel, 1999, and references herein) raise doubt about the temporal constancy of the used transfer functions, at least for Greenland.

Additional information is gained by analysis of the deuterium excess $d$ (defined as $d=$ $\delta D-8 \delta^{18} \mathrm{O}$ ). The strength of the deuterium excess signal is in general related to kinetic fractionation effects during evaporation, and can therefore be used as an indicator of changes in temperature and/or humidity at the evaporation site (Johnsen et al., 1989; Merlivat and Jouzel, 1979; Vimeux et al., 1999). Thus, a correct simulation of the deuterium excess represents a possible validation of the simulated moisture origins.

In this study, the Hamburg atmospheric general circulation model (AGCM) ECHAM-4 is used to investigate the coherency between isotopes, temperatures and source regions of precipitation falling on Greenland and Antarctica under the present and glacial climate. Both isotopes $\mathrm{H}_{2}{ }^{18} \mathrm{O}$ and $\mathrm{HDO}$ are explicitly simulated in the water cycle of the AGCM, and in addition the capability to trace water from different source regions was added to ECHAM-4. Our approach is comparable to the work of Joussaume et al. (1984) and Koster et al. (1992) but using a modern AGCM with a finer spatial resolution and a much longer simulation period. The independent simulation of isotope values and other physical parameters (e.g., surface temperatures) plus the simultaneous "tagging" of water vapor from different evaporation areas enables us to focus on the following questions: (1) What are the major source regions of the precipitation in Greenland and Antarctica for the present and the last glacial maximum (LGM) climate? (2) Can the major source areas contributing to the polar precipitation be identified by the mean isotopic signature $\left({ }^{18} \mathrm{O}\right.$ and deuterium excess $d$ ) of the precipitation? (3) Are water isotopes still a reliable proxy for LGM surface temperatures on the Greenland and Antarctic ice sheet?

\section{Model description and prescribed boundary conditions}

All results reported here are based on the Hamburg AGCM ECHAM-4 (Roeckner et al., 1996). Experiments were performed in T30 resolution $\left(3.75^{\circ} \times 3.75^{\circ}\right.$ on the physical grid, 19 vertical levels) running for 10 years with seasonally varying constant boundary conditions. The stable water isotopes $\mathrm{H}_{2}{ }^{18} \mathrm{O}$ and $\mathrm{HDO}$ are both explicitly cycled through the water cycle of the model (Hoffmann et al., 1998). The capability to trace water evaporating from different source regions was implemented by adapting the approach described by Joussaume et al. (1984): water masses from different source regions get a tag from their origin and can be identified as long as they are in the atmosphere. The tag is removed if the water reaches the surface as precipitation, dew and exchanged vapor. In total, we defined 14 different tagging areas (Fig. 1, left). For land surfaces, each continent was defined as a different evaporation source (source regions I to N). For ocean surfaces, the annual mean SST of each grid box was chosen to define several evaporation areas of the Atlantic and the Indopacific, respectively: source region $\mathrm{A}, \mathrm{H}$ : $\mathrm{SST} \leqslant 10^{\circ} \mathrm{C}$, source region $\mathrm{B}, \mathrm{C}$, $\mathrm{F}, \mathrm{G}: 10^{\circ} \mathrm{C}<\mathrm{SST}<25^{\circ} \mathrm{C}$, source region $\mathrm{D}, \mathrm{E}$ : $\mathrm{SST} \geqslant 25^{\circ} \mathrm{C}$. Compared to the present climate, the glacial oceanic evaporation regions vary in their spatial extent (due to the prescribed LGM SST) but represent the same SST intervals (Fig. 1, right) as in the present climate simulation.

The first tagging experiment was performed under present-day boundary conditions. For the second simulation we assumed LGM boundary conditions according to the outline of the Paleo Modeling Intercomparison Project (PMIP): SST and sea ice extent according to CLIMAP (1981), solar insolation according to the astronomical theory (Berger, 1978), a glacial $\mathrm{CO}_{2}$ value of 200 ppmv (Barnola et al., 1987), land surface and glacier distribution as reconstructed by Peltier (1994). In agreement with a new estimation of the glacial Greenland ice sheet elevation by Cuffey 

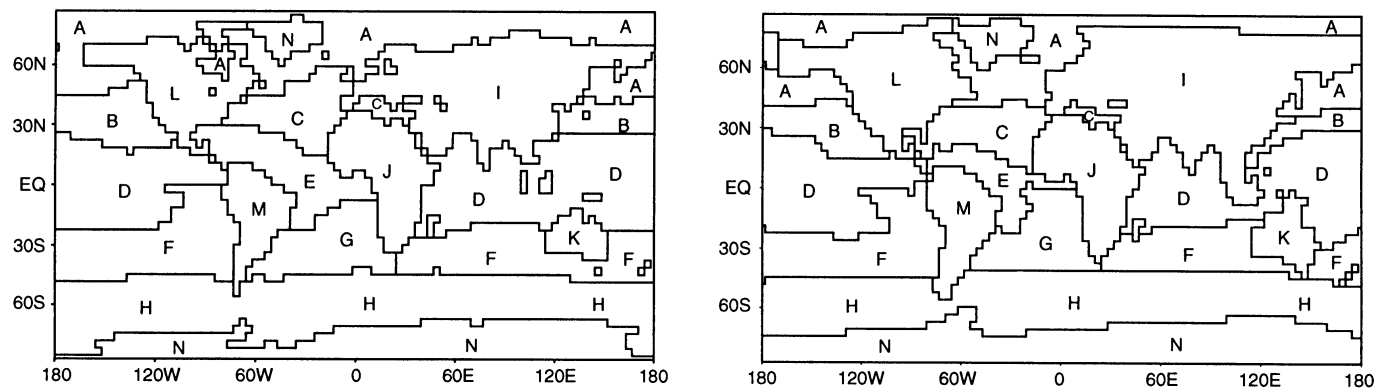

Fig. 1. Left: the definition of 14 different source regions of water vapor for the present-day climate. Evaporation from ocean surfaces is divided into 8 different areas (A: polar seas, B: northern Pacific, C: northern Atlantic, D: tropical Indopacific, E: tropical Atlantic, F: southern Indopacific, G: southern Atlantic, H: Antarctic Current) while each continent is separated as a unique source of water vapor (I: Eurasia, J: Africa, K: Australia, L: North America, M: South America, N: Greenland and Antarctica). Right: the same definition of source regions of water vapor for the LGM climate with prescribed CLIMAP SST. Compared to the present climate, the continent source regions are increased due to glacial sea level changes, while ocean source regions vary in their spatial extent due to changed LGM SST (see text).

and Clow (1997) the Peltier reconstruction of the Greenland ice sheet elevation change was reduced by three-quarters. No changes of the Peltier reconstruction were made for Antarctica.

There is a still ongoing discussion about the CLIMAP reconstruction of tropical glacial SSTs. Several authors claim the tropical CLIMAP SSTs as too warm (e.g., in Broecker (1996)). New measurements also indicate a partly ice-free north Atlantic during glacial summer periods (Weinelt et al., 1996). To account for these critics on CLIMAP SSTs we have performed an additional glacial sensitivity experiment with cooler tropical SST and a partly warmer north Atlantic: we used SSTs published by Webb et al. (1997) which are based on a AGCM simulation with the NASAGISS model $\left(8^{\circ} \times 10^{\circ}\right)$. Instead of fixed glacial SSTs, ocean heat convergence and associated transports close to present-day values were prescribed for the LGM climate. This different boundary condition leads to an enhanced cooling, particularly in the tropics, which is in agreement with recent geochemical evidence (Guilderson et al., 1994; Stute et al., 1995). The monthly mean SSTs are in the range of $1^{\circ}$ to $7^{\circ}$ cooler than CLIMAP SSTs (between $40^{\circ} \mathrm{S}$ and $40^{\circ} \mathrm{N}$ ) and also partly warmer in the north Atlantic. Monthly surface temperature fields of this LGM simulation by Webb et al. (1997) were interpolated to the finer spatial ECHAM grid and used as a boundary condition for our sensitivity study. All other glacial boundary conditions were set like in the LGM simulation with CLIMAP SSTs. One might argue that a re-run of the experiment layout of Webb et al. (1997) with the ECHAM AGCM might have been more consistent with our other performed LGM simulations. However, as a first sensitivity study of the influence of cooler tropical SST (and a partly warmer north Atlantic) the use of the results by Webb et al. (1997) should be sufficient.

\section{Results and discussion}

\subsection{Present climate}

3.1.1. Greenland: source areas and isotopic signature of present precipitation. In Fig. $2 \mathrm{a}$, the modeled spatial pattern of mean annual precipitation on Greenland is shown. Using a coarse model resolution of $3.75^{\circ} \times 3.75^{\circ}$ does not allow reproducing many small-scale features of the actual precipitation pattern observed on Greenland (Ohmura and Reeh, 1991). But the large scale trend of high precipitation amounts in the south (at Dye 3: observed: $54.1 \mathrm{~cm} \mathrm{a}^{-1}$, modeled: $90.4 \pm 14.6 \mathrm{~cm} \mathrm{a}^{-1}$ ), decreased values in the Summit region, central Greenland (observed: 24.0, modeled: $22.5 \pm 3.2 \mathrm{~cm} \mathrm{a}^{-1}$ ) and a very dry region in the north is reproduced by the ECHAM model. However, the extent of this dry region is over-estimated in western direction by our simulation. For example, precipitation values near Camp Century $\left(14.8 \pm 4.1 \mathrm{~cm} \mathrm{a}^{-1}\right)$ are more than twice lower than observed $\left(34.8 \mathrm{~cm} \mathrm{a}^{-1}\right)$. Overall, there 
a)

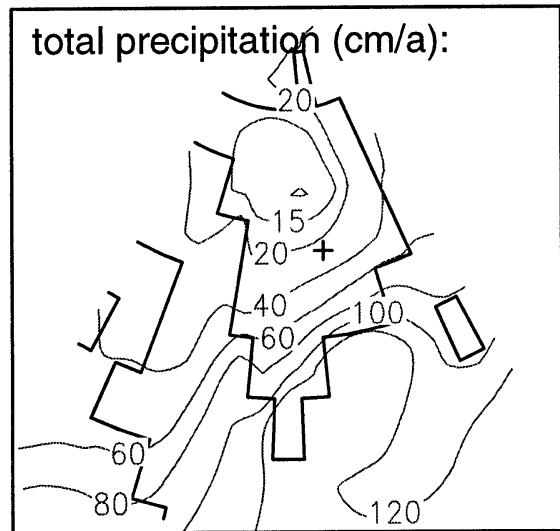

c)

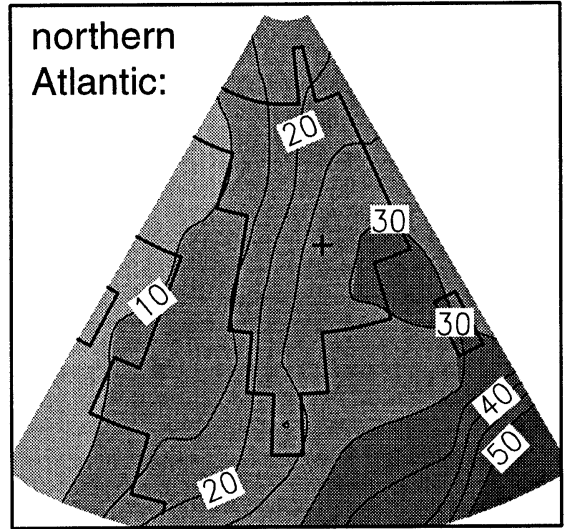

e)

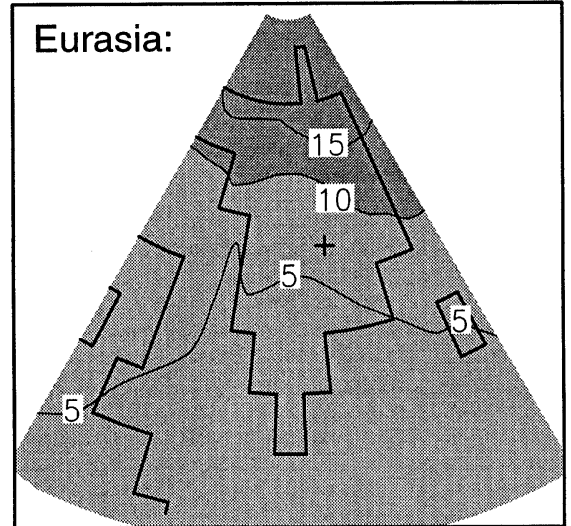

b)

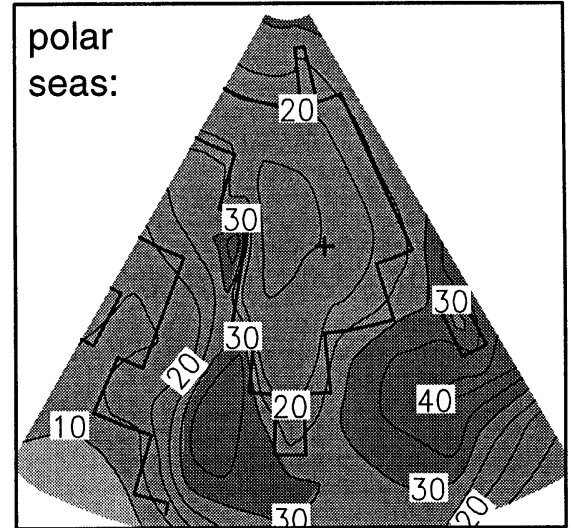

d)

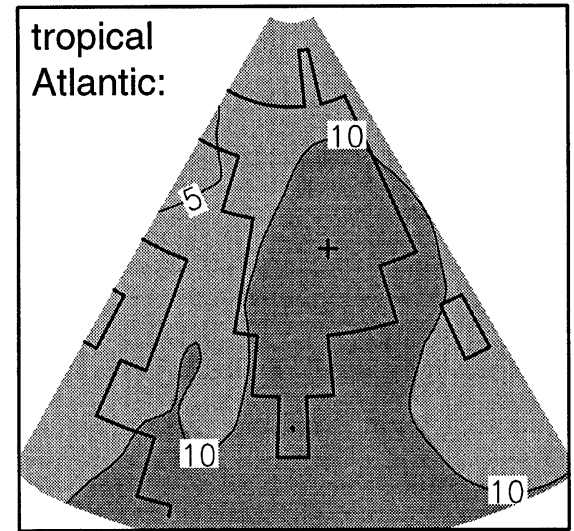

f)

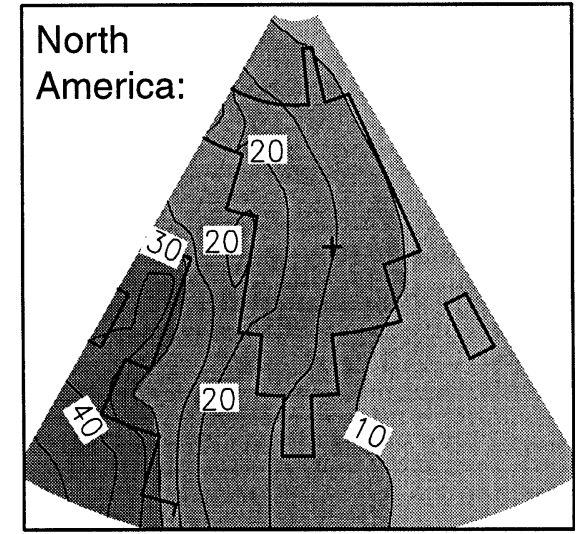

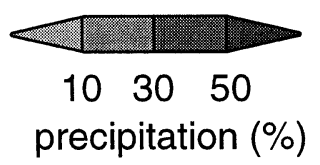

Fig. 2. (a) Modeled long-time mean precipitation values of Greenland for the present-day climate (contour lines at $\left.10,15,20,40,60,80,100,120 \mathrm{~cm} \mathrm{a}^{-1}\right) ;(\mathrm{b}-\mathrm{f})$ the relative contribution of different source areas (expressed as a \% of the modeled mean precipitation values, contour lines at every $5 \%$ ). The cross marks the Summit drill site. 
a)

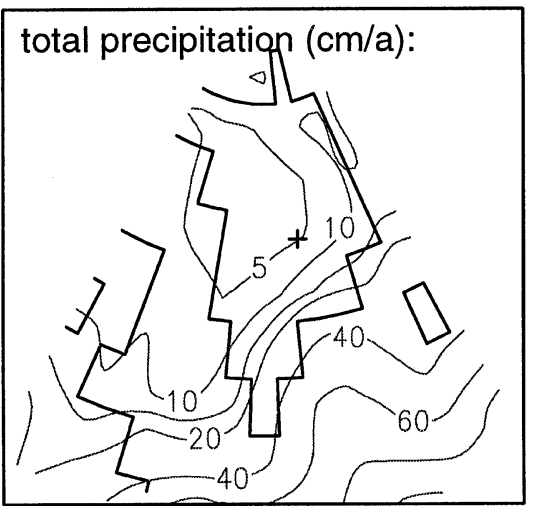

c)

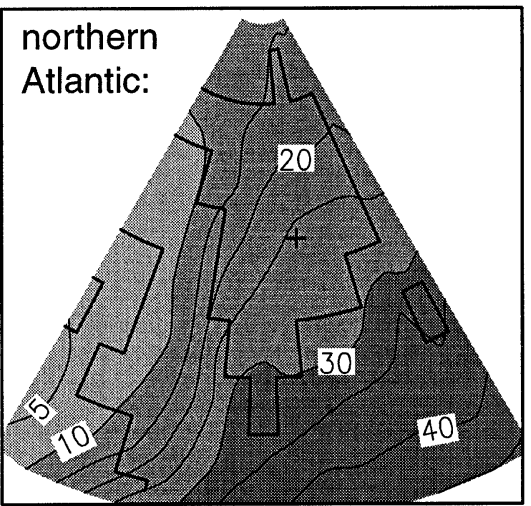

e)

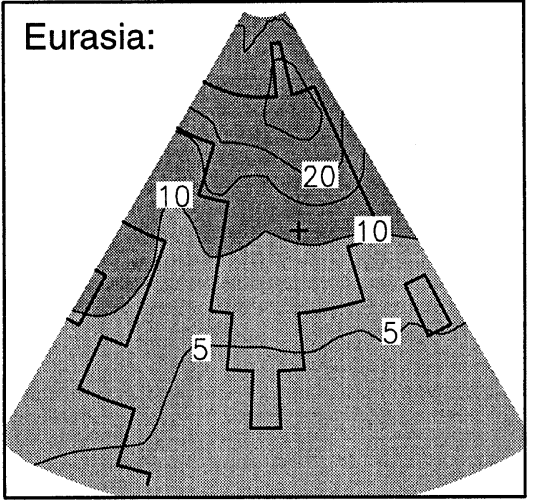

b)

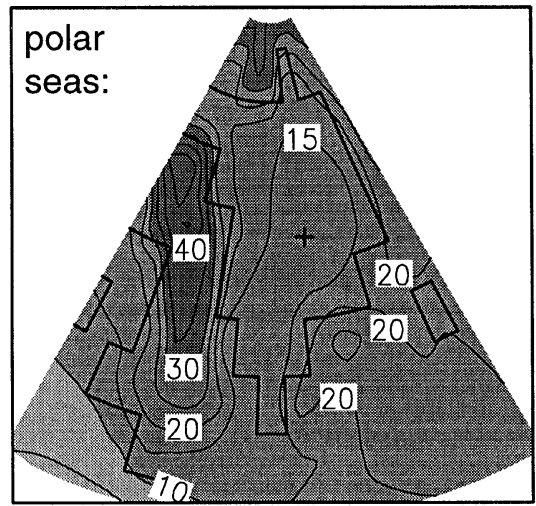

d)

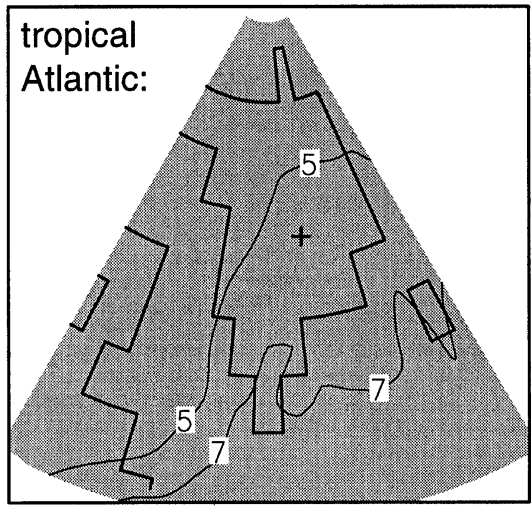

f)

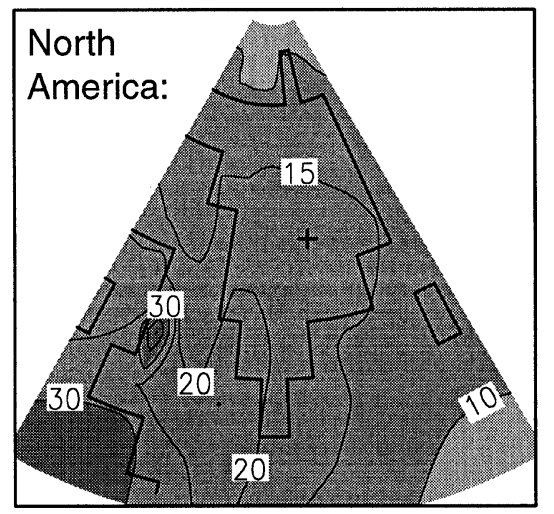

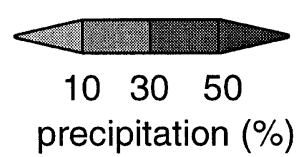

Fig. 3. (a) Modeled long-time mean precipitation values of Greenland for the LGM climate with prescribed CLIMAP SSTs (contour lines at 5, 10,15,20,40,60,80 $\mathrm{cm} \mathrm{a}^{-1}$ ); (b-f) the relative contribution of different source areas (expressed as a $\%$ of the modeled mean precipitation values, contour lines at every $5 \%$, extra contour line at $7 \%$ in (d)). The cross marks the Summit drill site. 
seems to be a too large modeled latitudinal gradient in precipitation over the Greenland ice sheet (too low values at Dye 3, too high values at Camp Century). In addition, the high accumulation belt on the west coast is missing, probably due to an under-representation of circulation on a synoptical scale in connection with topography. In the simulation, precipitation stems from 7 different source regions. Water from the polar seas surrounding Greenland (source region A, annual mean $\mathrm{SST} \leqslant 10^{\circ} \mathrm{C}$ ) is mainly transported to coastal regions with a slightly lower gradient of decreasing precipitation amounts at the western coast of Greenland than at the eastern coast (Fig. 2b). Besides the polar seas, we see two major source regions of water transported to Greenland: the mid-latitudinal and subtropical Atlantic regions (source region $\mathrm{C}$, annual mean SST between $10^{\circ} \mathrm{C}$ and $25^{\circ} \mathrm{C}$ ) and the North American continent (source region L). While the main transport direction for north Atlantic water masses is from the east (Fig. 2c) and can be associated with the Icelandic Low, water from the North American continent reaches Greenland from a southwesterly direction (Fig. 2f). Smaller oceanic water contribution to Greenland's precipitation stem from the tropical Atlantic (source region E, annual mean $\mathrm{SST} \geqslant 25^{\circ} \mathrm{C}$, Fig. 2d) and from the Pacific (not shown). Besides North America, the Eurasian land surface (source I) is another continental water source. Water from Eurasia reaches Greenland not from the east, but from the very north, following the circumpolar circulation (Fig. 2e). Simulated year-by-year variations of the contribution of different oceanic or land water source regions are in the range of $5 \%$ to $20 \%$ of the annual mean ( $1 \sigma$ standard deviation). However, this interannual variability might be limited by the prescribed seasonally varying but yearly constant SST.

Previous studies with simpler transport models have concluded from the observed isotopic composition of the precipitation that the dominating water masses found in central Greenland stem from the subtropical part of the north Atlantic ocean (Hoffmann et al., 1997; Johnsen et al., 1989). In Table 1 we have listed $\delta^{18} \mathrm{O}$ and $d$ values of all source regions with a significant contribution (i.e., $>5 \%$ of the total precipitation) to the precipitation falling in the model grid box enclosing the Summit region. The simulated annual mean $\delta^{18} \mathrm{O}$ value $(-30.1 \pm 0.7 \%)$ is somewhat lower than the ice core data $(-34.8 \pm 0.1 \%$, Grootes et al., 1993) but this deviation is mainly caused by the coarse model resolution (the grid box enclosing the Summit area is $500 \mathrm{~m}$ lower than the true Summit location). The modeled mean excess $d=$ $9.6 \pm 0.6 \%$ is close to the GRIP ice core data $(d=$ $8.8-9.3 \%$, Hoffmann et al., 1997). The analysis of the $\delta$-values of different source regions shows that the results of our AGCM simulation are in good agreement with the earlier findings. Water which stems from subtropical Atlantic regions (= transition region betwen sources $\mathrm{C}$ and $\mathrm{E}$ ) has presumably an isotopic signature similar to the one of the total precipitation amount. The additive contribution of these regions represents about $42 \%$ of the precipitation in the Summit area. The subtropical and tropical Atlantic is therefore the most important source region for central Greenland. But two other important aspects can also be seen from Table 1: (1) Other sources of water vapor with a different isotopic composition than measured in the ice cores (more enriched in heavy isotopes: polar seas, more depleted: Pacific sources) contribute also a non-negligible part to the total precipitation amount falling in the Summit region. (2) Water from the North American continent has a very similar isotopic composition as water from the northern Atlantic. Thus, the isotopic signature of the total precipitation amount falling at Summit is a reliable indicator for the major source area (source regions $\mathrm{C}$ and $\mathrm{E}$ ) but it does not reveal information about precipitation from other source regions with counterbalancing isotopic compositions. Similar to this ECHAM-4 simulation, two studies to identify the major source regions of Greenland's precipitation with the GISS AGCM (Armengaud et al., 1998; Charles et al., 1994) report also a significant contribution of continental water and a minor contribution of far-distanced Pacific water transported to Greenland.

3.1.2. Antarctica: source areas and isotopic signature of present precipitation. The simulated precipitation amounts of our present-day simulation (Fig. 4a) are similar to ECMWF reanalyzes results (Cullather et al., 1998). Like for the Greenland ice sheet, many small-scale features are not represented by the coarse model resolution. But the very dry inner region of east Antarctica 
Table 1. Modeled precipitation amounts ( \pm standard deviation $1 \sigma$ ) and isotopic composition of water masses from different source regions transported to the Summit region, central Greenland, and the Vostok region, east Antarctica, respectively; the relative contributions (\%) of the different water sources to the total precipitation amount are given in brackets

\begin{tabular}{|c|c|c|c|c|c|c|}
\hline & \multicolumn{3}{|c|}{ Summit } & \multicolumn{3}{|c|}{ Vostok } \\
\hline & $\begin{array}{c}\text { Prec. } \\
\left(\mathrm{cm} \mathrm{a}^{-1}\right)\end{array}$ & $\begin{array}{c}\delta^{18} \mathrm{O} \\
(\% 0)\end{array}$ & $\begin{array}{c}d \\
(\% 0)\end{array}$ & $\begin{array}{c}\text { Prec. } \\
\left(\mathrm{cm} \mathrm{a}^{-1}\right)\end{array}$ & $\begin{array}{c}\delta^{18} \mathrm{O} \\
(\% 0)\end{array}$ & $\begin{array}{c}d \\
(\% 0)\end{array}$ \\
\hline observed: total & 23 & -34.8 & 9 & 2.3 & -57.2 & 16.3 \\
\hline modeled: total & $\begin{array}{c}22.6 \pm 3.3 \\
(100 \%)\end{array}$ & -30.1 & 9.6 & $\begin{array}{c}0.9 \pm 0.1 \\
(100 \%)\end{array}$ & -49.3 & 21.0 \\
\hline polar seas & $\begin{array}{c}3.4 \pm 0.4 \\
(15 \%)\end{array}$ & -19.8 & -3.5 & - & - & - \\
\hline northern Atlantic & $\begin{array}{c}6.3 \pm 1.3 \\
(28 \%)\end{array}$ & -26.7 & 4.2 & - & - & - \\
\hline tropical Atlantic & $\begin{array}{c}3.1 \pm 0.6 \\
(14 \%)\end{array}$ & -31.5 & 11.4 & - & - & - \\
\hline southern Atlantic & - & - & - & $\begin{array}{c}0.1 \pm 0.02 \\
(11 \%)\end{array}$ & -52.4 & 27.2 \\
\hline northern Pacific & $\begin{array}{c}1.8 \pm 0.3 \\
(8 \%)\end{array}$ & -41.1 & 19.0 & - & - & - \\
\hline tropical Indopacific & $\begin{array}{c}2.2 \pm 0.4 \\
(10 \%)\end{array}$ & -46.6 & 31.3 & $\begin{array}{c}0.1 \pm 0.02 \\
(44 \%)\end{array}$ & -62.2 & 53.8 \\
\hline southern Indopacific & - & - & - & $\begin{array}{c}0.4 \pm 0.06 \\
(22 \%)\end{array}$ & -48.7 & 16.9 \\
\hline Antarctic Current & - & - & - & $\begin{array}{c}0.2 \pm 0.04 \\
(22 \%)\end{array}$ & -39.7 & -1.2 \\
\hline Eurasia & $\begin{array}{c}1.4 \pm 0.1 \\
(6 \%)\end{array}$ & -31.5 & 15.3 & - & - & - \\
\hline North America & $\begin{array}{c}3.5 \pm 0.5 \\
(15 \%)\end{array}$ & -24.9 & 5.5 & - & - & - \\
\hline South America & - & - & - & $\begin{array}{c}0.05 \pm 0.01 \\
(6 \%)\end{array}$ & -51.0 & 16.5 \\
\hline
\end{tabular}

around the Vostok drill site (precipitation values as low as $1 \mathrm{~cm} \mathrm{a}^{-1}$ ) is fairly well represented in the simulation. The major simulated water sources contributing to the present-day precipitation of Antarctica are the southern Indopacific (source region $\mathrm{F}$, annual mean $\mathrm{SST}$ between $10^{\circ} \mathrm{C}$ and $25^{\circ} \mathrm{C}$ ), the southern Atlantic (source region $\mathrm{G}$, annual mean SST between $10^{\circ} \mathrm{C}$ and $25^{\circ} \mathrm{C}$ ) and the Antarctic Current ACC (source $\mathrm{H}$, annual mean $\mathrm{SST} \leqslant 10^{\circ} \mathrm{C}$ ). Water from the southern Atlantic is mainly transported to a wedge-shaped sector between $0^{\circ}$ and $90^{\circ} \mathrm{E}$ (Fig. $4 \mathrm{~d}$ ), and the strongest contribution of southern Indopacific water can be found west and east of the Ross iceshelf between $100^{\circ} \mathrm{E}$ and $120^{\circ} \mathrm{W}$ (Fig. 4c). The relative water contribution of the ACC is $10-15 \%$ higher in west Antarctica than in east Antarctica (Fig. 4e). An additional small amount of tropical
Indopacific water (source region $\mathrm{D}$, annual mean $\mathrm{SST} \geqslant 25^{\circ} \mathrm{C}$ ) is transported to west Antarctica in the simulation (Fig. 4b). In Queen Maud Land, about $10 \%$ of the precipitation amount stems from the South American continent (source M, Fig. 4f). The year-by-year variations $(1 \sigma)$ of different water vapor sources contributing to the Antarctic precipitation are in the range of $10-20 \%$ of the annual mean. Like for Greenland, the prescribed yearly constant SST might limit the simulated interannual variability.

In contrast to the Summit drill site in central Greenland, continental water sources can be neglected for the Vostok drill site in central Antarctica. As shown in Table 1, the modeled precipitation stems from the tropical Indopacific $(11 \%)$, the southern Indopacific (44\%), the southern Atlantic $(11 \%)$ and the Antarctic Current (22\%). This is

Tellus 53B (2001), 1 
a)

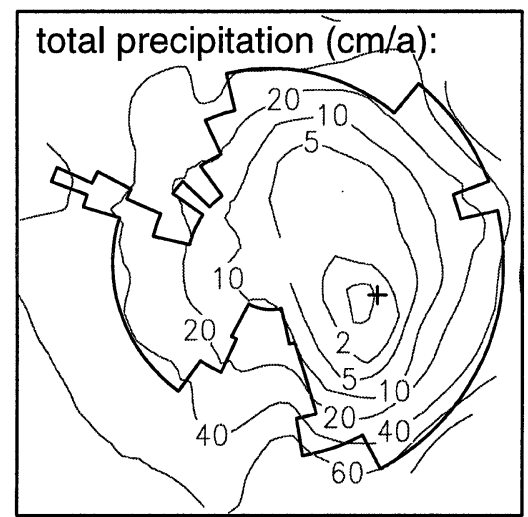

c)

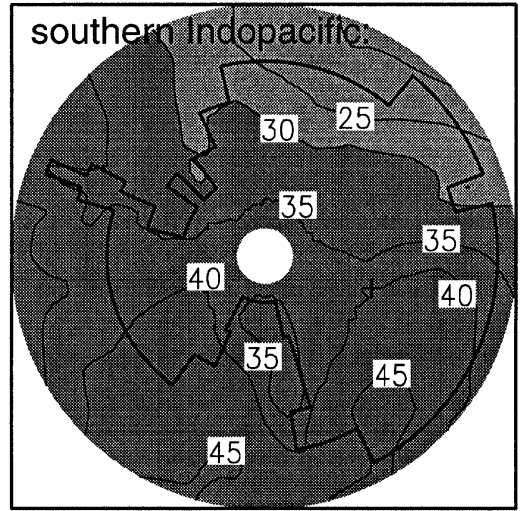

e)

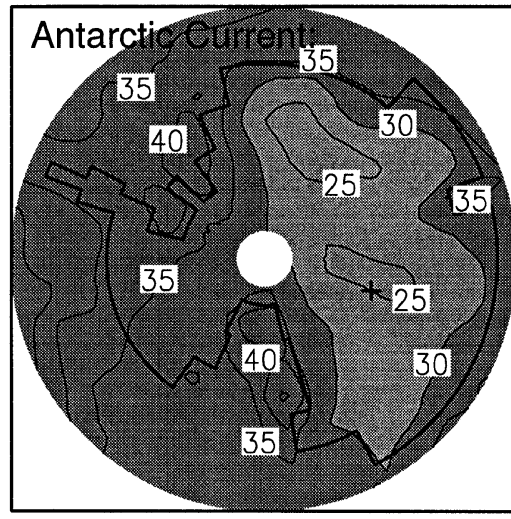

b)

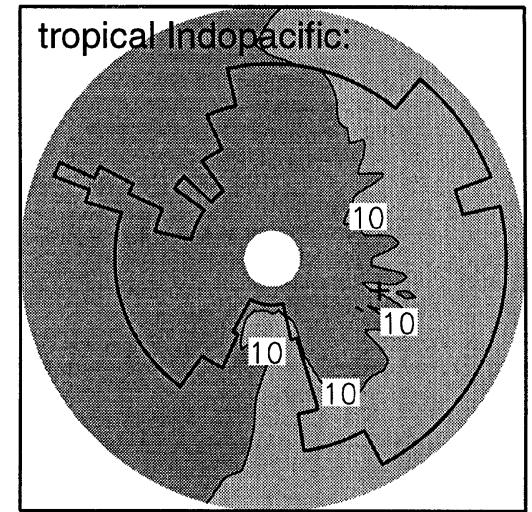

d)

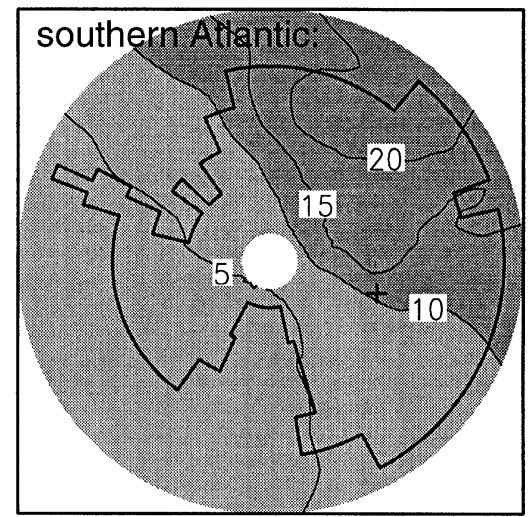

f)

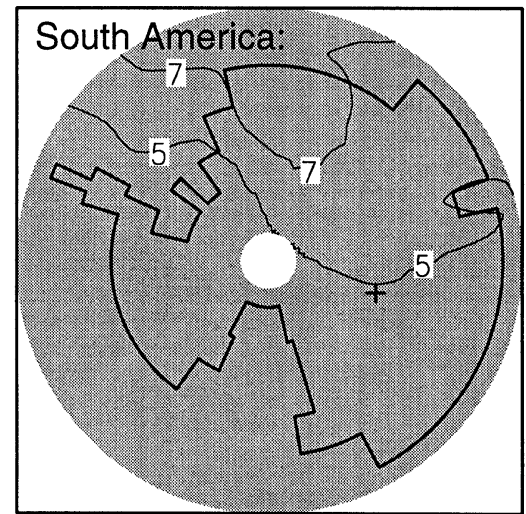

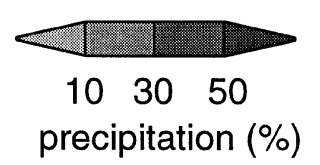

Fig. 4. (a) Modeled long-time mean precipitation values of Antarctica for the present-day climate (contour lines at $\left.1,2,5,10,20,30,40,50,60,70 \mathrm{~cm} \mathrm{a}^{-1}\right) ;(\mathrm{b}-\mathrm{f})$ the relative contribution of different source areas (expressed as a \% of the modeled mean precipitation values, contour lines at every $5 \%$, extra contour line at $7 \%$ in (f)). The cross marks the Vostok drill site. 
a)

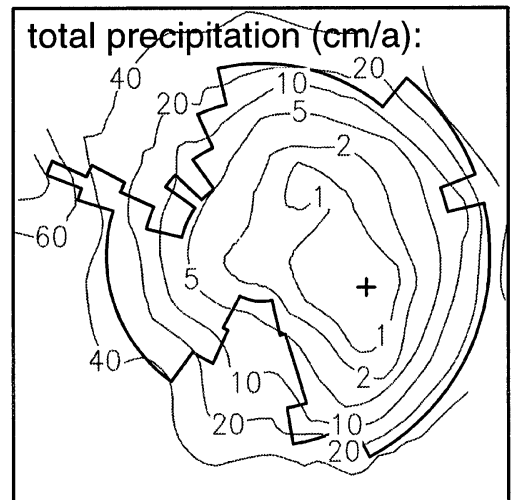

c)

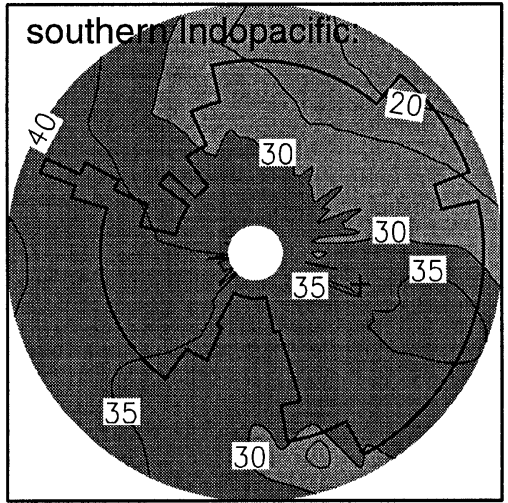

e)

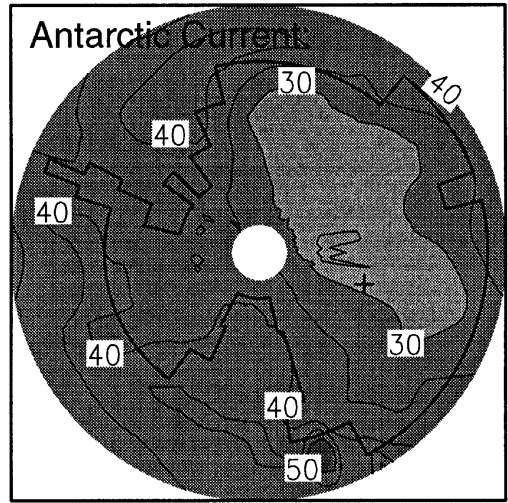

b)

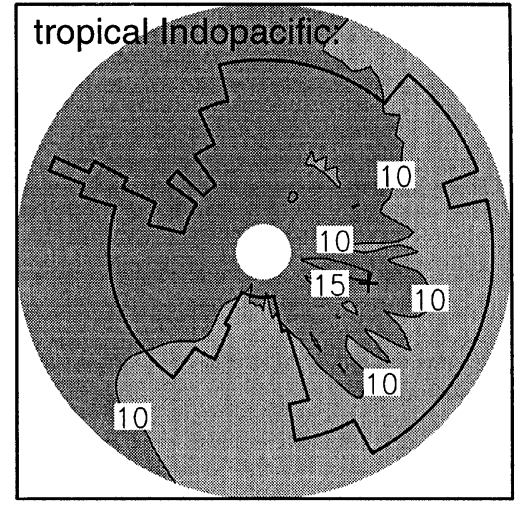

d)

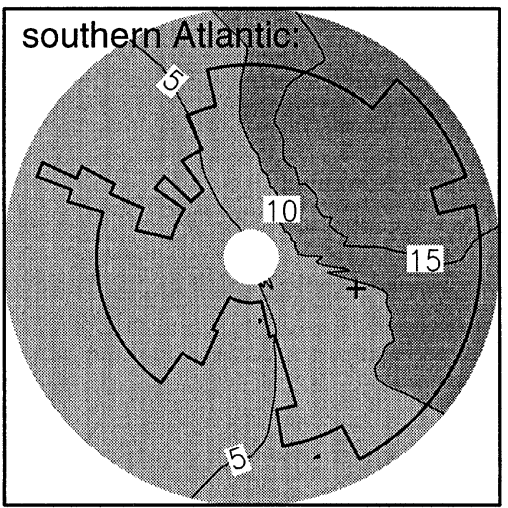

f)

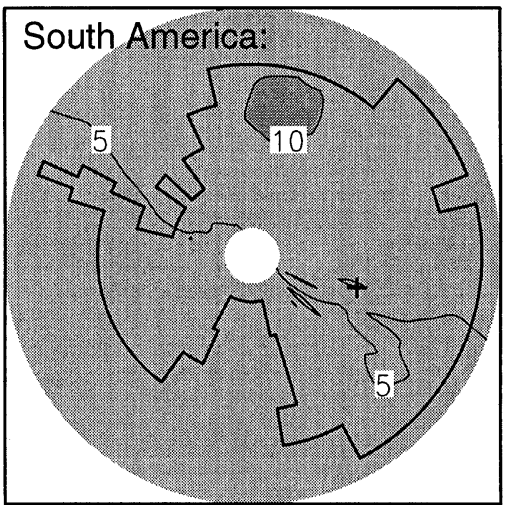

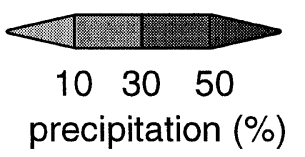

Fig. 5. (a) Modeled long-time mean precipitation values of Antarctica for the LGM climate with prescribed CLIMAP SSTs (contour lines at $\left.1,2,5,10,20,30,40,50 \mathrm{~cm} \mathrm{a}^{-1}\right) ;(\mathrm{b}-\mathrm{f})$ the relative contribution of different source areas (expressed as a $\%$ of the modeled mean precipitation values, contour lines at every $5 \%$ ). The cross marks the Vostok drill site. 
in agreement with previous studies of the deuterium excess from coastal and central Antarctica observations, which suggested a major subtropical source but could not exclude an additional coastal water contribution (Ciais et al., 1995). Results are also similar to tagging experiments of Delaygue (2000) using the GISS AGCM. Like for Summit, Greenland, the isotopic composition of water from the major source region (region $\mathrm{F}$, the southern Indopacific) is very similar to the $\delta$-values of total precipitation. But water from other source regions (either more depleted or enriched in $\mathrm{H}_{2}{ }^{18} \mathrm{O}$ ) contributes a non-negligible part to the precipitation at Vostok, too. The isotopic results for Antarctica, however, deviate stronger from the observations than in Greenland though the deviation is in the same direction, e.g., at Vostok: modeled $\delta^{18} \mathrm{O}=$ $-49.3 \%$, observed $\delta^{18} \mathrm{O}=-57.2 \%$ (Dahe et al., 1994). One might argue that an overestimation of water transport from coastal regions causes the too high $\delta^{18} \mathrm{O}$ values in the model. But as seen in Table 1, an increased water contribution from different sources would not only lead to lower $\delta^{18} \mathrm{O}$ values, but also increase the simulated deuterium excess values $(d=21.0 \%$ o), which is in contrast to the observed value $d=16.3 \%$ (Dahe et al., 1994). Thus, the reason for this model mismatch remains unclear.

The problem of matching $\delta^{18} \mathrm{O}$ and $d$ values is illustrated in Fig. 6, where the ${ }^{18} \mathrm{O}$ composition for the different source regions of both Summit and Vostok is plotted against their respective deuterium excess value of $d$. The GCM nicely reproduce what we would expect from a simple Rayleigh distillation model (Dansgaard, 1964): the warmer and therefore more distant from the polar deposition site the vapor source is situated the lower is the corresponding $\delta$ value. This holds since what is really controlling the isotopic composition of polar precipitation is the temperature difference between the evaporation and the condensation site. On the other hand, the deuterium excess is largely affected by the climatic condition prevailing at the evaporation site. Warmer sea surface temperatures provoke isotopic non-equilibrium conditions during evaporation and thus enhance the deuterium excess (Merlivat and Jouzel, 1979). Since there is a kinetic (nonequilibrium) effect during snow formation, too, the deuterium excess is also influenced by condensation temperatures. However, since the con- densation temperature is the same for all different vapor sources we see in Fig. 6 just the effect of the varying source temperatures. This explains why increasing evaporation temperatures produce both lower isotope values $\left(\delta^{18} \mathrm{O}\right.$ and $\left.\delta \mathrm{D}\right)$ and higher deuterium excess as can be seen in Fig. 6. Thus, the dilemma for the isotopic composition in central Antarctica and to a lesser extent for Greenland reads like this: any mixture of source regions deviating from the simulated one will not diminish the model-observation difference $\left(\delta^{18} \mathrm{O}\right.$ and $\left.d\right)$ since the mean isotopic composition will just move along the fitted line in Fig. 6 . This clearly points to parameterization problems of the water isotopes, particularly of the deuterium excess which is as a second order quantity more sensitive to the description of kinetic processes in the model.

\subsection{LGM climate}

3.2.1. Source areas of glacial precipitation. Greenland. It has been proposed that changes in the circulation and water vapor transport pathways to Greenland might have occurred during the LGM (Kapsner et al., 1995). Our simulation under LGM climate boundary conditions with CLIMAP SSTs shows no major changes of the most important source regions of Greenland precipitation (Fig. 3). While the total amount of precipitation on Greenland is reduced by a factor 3-4 during the glacial climate (Fig. 3a) the most important source regions are still the nearby polar sea, the north Atlantic, the North American continent and Eurasia. The main transport directions of water from the north Atlantic and North America have both shifted to a more southern flow compared to the present-day climate (Fig. 3f). The small contribution of the tropical Atlantic region is reduced by about $5-7 \%$ during the LGM (Fig. 3d). The circumpolar circulation seems increased in the LGM simulation. Consequently the contribution of the Eurasian water source is now larger, especially in North Greenland (Fig. 3e). There exists also a minor contribution of Pacific water comparable in relative size to the present climate (not shown). Our findings are comparable to results of Charles et al. (1994) but in contrast to their work, we do not find a relative increase in the small Pacific water contribution for the LGM climate. In our sensitivity study with much cooler tropical SSTs and a partly warmer 


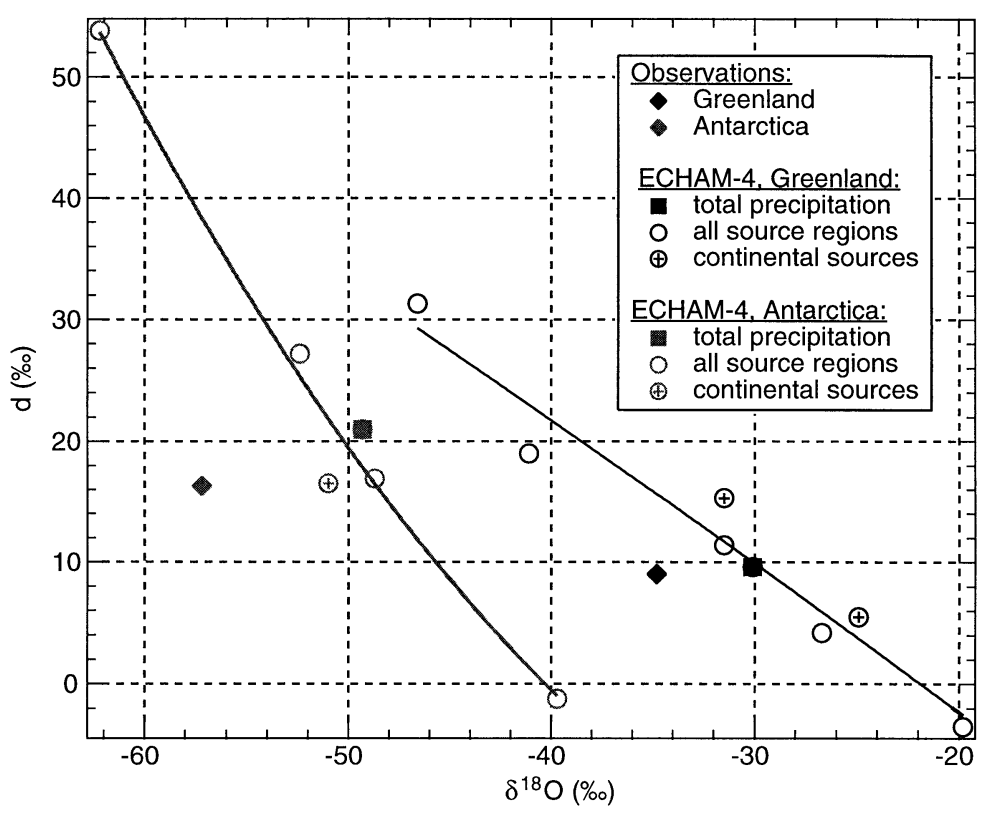

Fig. 6. Relation between $\delta^{18} \mathrm{O}$ and deuterium excess $d$ in precipitation at the Summit drill site, Greenland, and the Vostok drill site, Antarctica (measurements: solid rhombi, simulation values: solid squares). In addition, simulated $\delta^{18} \mathrm{O}$ and $d$ values of water from different source areas are plotted (open circles). Model values were fitted by a cubic polynom function (solid lines).

north Atlantic we observe very similar results as for a glacial climate using CLIMAP SSTs: the major source regions are again the polar seas, the northern Atlantic and the North American continent. Due to warmer, partly ice-free Norwegian Sea the relative contribution of water from the polar seas and the north Atlantic to Greenland increases by $15-20 \%$ cmpared to the CLIMAP LGM simulation.

Antarctica. For the LGM simulation under CLIMAP boundary conditions we observe a reduction of precipitation, especially in the interior areas of both west and east Antarctica (Fig. 5a). The driest region is still the Vostok area with mean and annual precipitation values as low as $0.6 \mathrm{~cm} \mathrm{a}^{-1}$. Analyzing the relative contribution of different source areas reveals a split of the Antarctic continent into two parts: between $90^{\circ} \mathrm{W}$ and $90^{\circ} \mathrm{E}$ the different precipitation source regions (most important: southern Atlantic ocean) have not changed in their relative contribution to the total precipitation amount. But for the area between $90^{\circ} \mathrm{E}$ and $90^{\circ} \mathrm{W}$ the relative strength of the southern Pacific source is reduced by $5-15 \%$ under the glacial climate (Fig. 5c), while the contribution of water from the Antarctic Current region has increased by up to $10 \%$ (Fig. 5e). If cooler tropical SSTs are prescribed instead of the CLIMAP SST data, the relative contribution of water from the Atlantic or Indopacific is reduced by about $15-20 \%$, and the amount of coastal waters transported to the Antarctic ice sheet is increased instead. In contrast to these ECHAM-4 results (with a spatial resolution of $3.75^{\circ} \times 3.75^{\circ}$ ), Delaygue et al. (2000) report an increased transport of water from subtropical regions and a decreased transport of coastal water to Antarctica for an LGM simulation with CLIMAP SSTs using the GISS AGCM (with $8^{\circ} \times 10^{\circ}$ spatial resolution). Similar to our sensitivity study, an additional GISS simulation with cooler tropical glacial SSTs results in a minor influence of subtropical water masses due to a decreased meridional ocean surface temperature gradient (Delaygue et al., 2000).

3.2.2. The isotopic signature of glacial precipitation. In Table 2, we have listed observed (or 
Table 2. Observed (or estimated) versus simulated anomalies $\Delta$ of glacial minus present values of surface temperature $T_{s}$, precipitation amounts, isotopic composition $\delta^{18} \mathrm{O}$ and deuterium excess $d$

\begin{tabular}{llccc}
\hline & $\begin{array}{c}\text { Observed: } \\
\text { LGM - present }\end{array}$ & $\begin{array}{c}\text { Modelled: } \\
\text { LGM - present }\end{array}$ & $\begin{array}{c}\text { Modelled: } \\
\text { cool tropics - CLIMAP }\end{array}$ \\
\hline Summit: & $\Delta T_{\mathrm{s}}\left({ }^{\circ} \mathrm{C}\right)$ & -18 to -23 & $-23.5 \pm 2.7$ & +7.0 \\
& $\Delta$ Prec. $\left(\mathrm{cm} \mathrm{a}^{-1}\right)$ & -16 to -17.5 & $-18.1 \pm 5.2$ & +2.2 \\
& $\Delta \delta^{18} \mathrm{O}(\%)$ & -6.2 to -8.2 & $-4.1 \pm 2.6$ & +1.2 \\
& $\Delta d(\%)$ & $-3^{\mathrm{a})}$ & $+0.3 \pm 1.5$ & -2.1 \\
Vostok: & $\Delta T_{\mathrm{s}}\left({ }^{\circ} \mathrm{C}\right)$ & -6 & $-10.0 \pm 1.4$ & -6.5 \\
& $\Delta$ Prec. $\left(\mathrm{cm} \mathrm{a}^{-1}\right)$ & -1 to -1.2 & $-0.4 \pm 0.3$ & -0.3 \\
& $\Delta \delta^{18} \mathrm{O}(\%)$ & -3 to -5 & $-7.7 \pm 5.4$ & -7.1 \\
& $\Delta d(\%)$ & -2 & $+5.2 \pm 11.7$ & +9.2 \\
\hline
\end{tabular}

a) Jean Jouzel, personal communication.

In the right column the modeled anomalies for LGM simulations using cooler tropical SST minus CLIMAP SST are given. Observed values in the left column are compiled from Cuffey and Clow (1997), Grootes et al. (1993), Lorius (1989), Lorius et al. (1985).

estimated) versus simulated glacial anomalies $\Delta$ of surface temperature $T_{\mathrm{s}}$, precipitation amount, $\delta^{18} \mathrm{O}$ and deuterium excess $d$ for both Summit, Greenland, and Vostok, Antarctica. For Summit, simulated anomalies $\Delta T_{\mathrm{s}}, \Delta$ precipitation and $\Delta \delta^{18} \mathrm{O}$ agree well with the estimates, although the simulated glacial $\Delta \delta^{18} \mathrm{O}$ anomaly is $2-4 \%$ o less than observed. But the LGM simulation with CLIMAP SSTs clearly fails to model the observed glacial drop of $-3 \%$ of the deuterium excess $\Delta d$ (Jean Jouzel, personal communication). Similar results are found for the Vostok region in the simulation: although deviations of $\Delta T_{\mathrm{s}}, \Delta$ precipitation and $\Delta \delta^{18} \mathrm{O}$ between ice core estimates and model values are larger than for central Greenland, the sign and magnitude of the modeled anomalies are correct. But like for Summit, an erroneous positive deuterium excess anomaly $\Delta d$ is found in the LGM simulation. Apparently, the ECHAM-4 model fails to simulate an observed glacial drop of the deuterium excess for both polar regions and neither cooler tropical SSTs (Table 2) nor a changed mixture of moisture sources would resolve this mismatch: any process resulting in a lower (higher) deuterium excess value also leads to higher (lower) $\delta^{18} \mathrm{O}$ values and vice versa, as demonstrated for the present climate in Fig. 6. Thus, from our LGM climate simulations it is not understood how a glacial decrease of both $\delta^{18} \mathrm{O}$ and the deuterium excess $d$ could be achieved. One might argue that some fundamental changes of the LGM climate compared to the present situation (e.g., changes in cloud microphysics by a larger dust content of the atmosphere) cause the failure of the reported LGM isotope simulations. But further model simulations are needed to test this hypothesis. In this context it is interesting to mention that similar problems of modeling correct glacial isotope and deuterium excess anomalies are reported for the GISS AGCM (G. Delaygue, personal communication).

\subsection{The temporary isotope-temperature relations}

Recently, paleo-temperature estimates by borehole thermometry (Cuffey et al., 1995; Dahl-Jensen et al., 1998; Johnsen et al., 1995) and gas diffusion measurements (Severinghaus et al., 1998) have questioned the use of spatial $\delta^{18} \mathrm{O}-T_{\mathrm{s}}$-relations to calculate past temperature changes on Greenland and Antarctica. In this chapter we therefore focus on the modeled isotope-temperature-relations on both ice sheet under the present and glacial climate to compare our model results to those new findings.

Greenland. In previous articles (Krinner et al., 1997; Werner et al., 2000) it was discussed in detail how the significant change of the seasonal distribution of precipitation seen in LGM simulations on Greenland (Fig. 7) results in a disagreement between temporal and spatial $\delta^{18} \mathrm{O}-T_{\mathrm{s}}$-relations (Fig. 9). In the context of this article we extend our previous findings and analyze how the different source contributions of Greenland's precipita- 

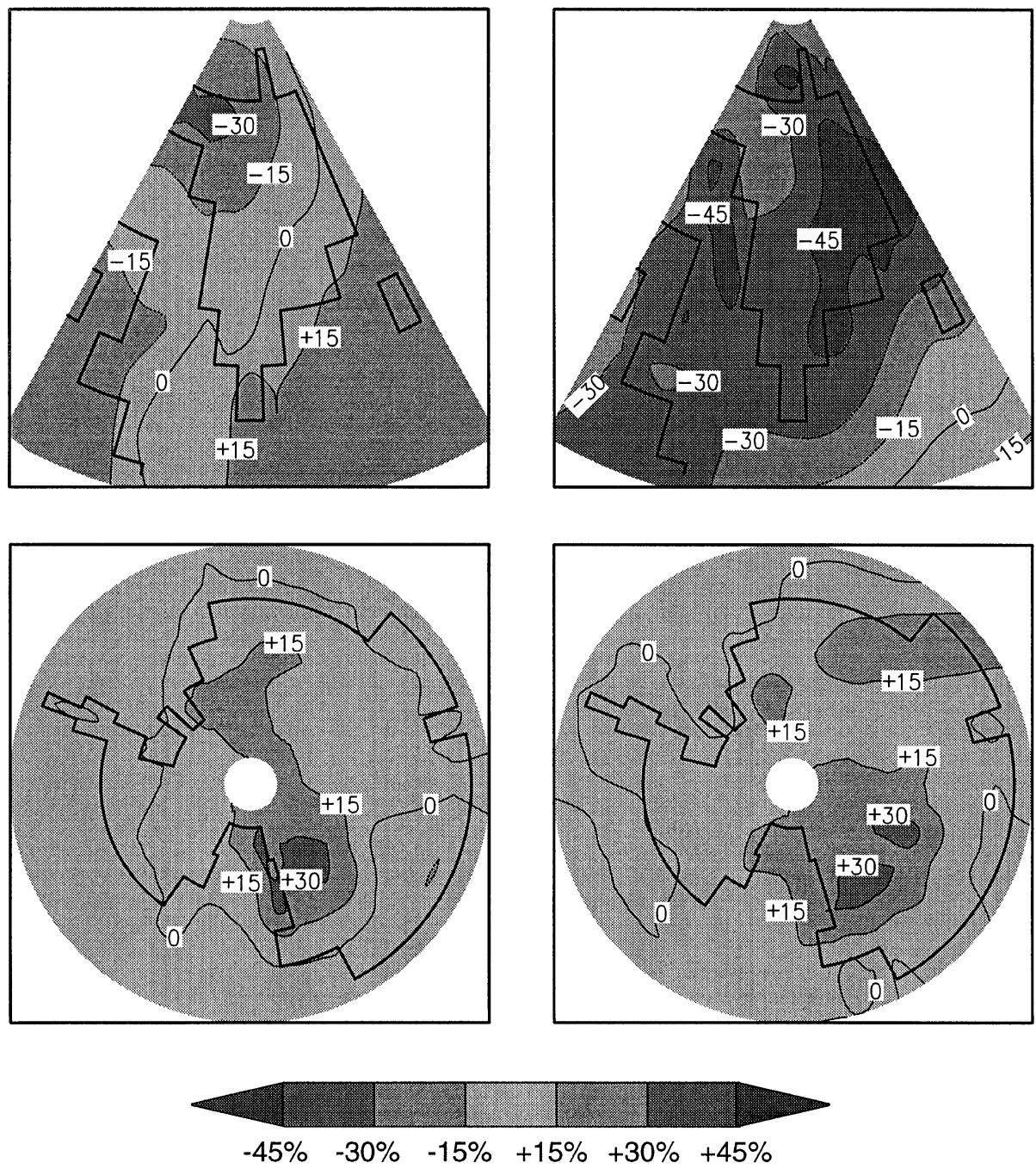

Fig. 7. Difference between winter (DJF) minus summer (JIA) precipitation values on the Greenland (top) and Antarctic (bottom) ice sheet for the simulated present (left) and glacial (right) climate. The seasonal differences are expressed as a $\%$ of the modeled mean precipitation values.

tion are affected by this change in seasonality. In Fig. 8, the mean seasonal contributions of modeled precipitation values of the grid box enclosing Summit are plotted for the present and glacial climate. A clear seasonal signal in the amount of precipitation is not seen in our present-day simulation, but slightly higher values in late summer/early autumn and the small minimum in late winter/early spring have been reported before (Bromwich et al., 1993). The seasonal influence of different source regions can be grouped as follows: water from both North America and Eurasia reaches Summit mainly in summer and can be neglected for winter precipitation. A summer maximum is also seen for the small water contribution, which stems from the tropical Pacific. Conversely, because of higher oceanic evaporation fluxes south of Greenland and in the GIN Sea in winter compared to summer, water from nearby polar sea tagging area reaches Summit mostly in winter. The north Atlantic and north Pacific regions do not show a well-defined seasonality but larger 


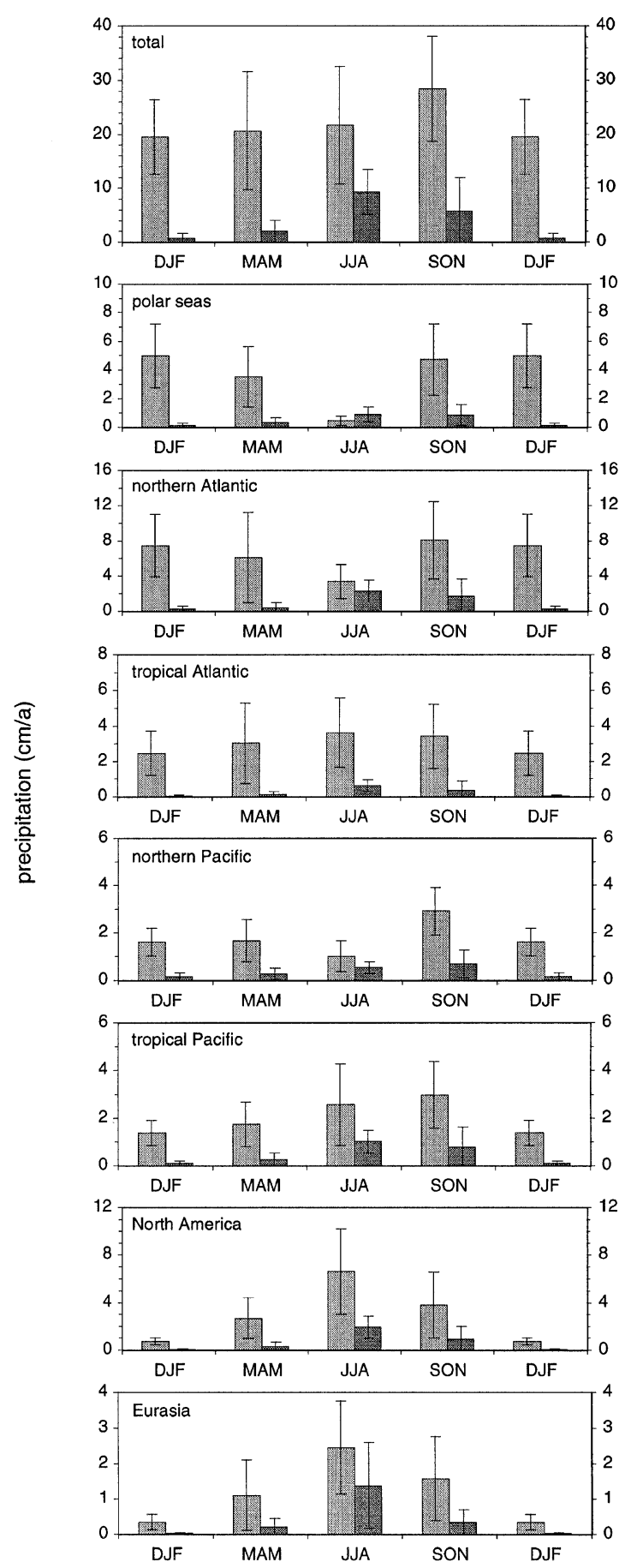

Fig. 8. Simulated seasonal mean values of the total precipitation and of all major source areas contributing to the precipitation falling at Summit for the simulated present and glacial climate. All values are expressed in $\mathrm{cm} \mathrm{a}^{-1}$, the winter season DJF is shown twice for clarity reasons. 

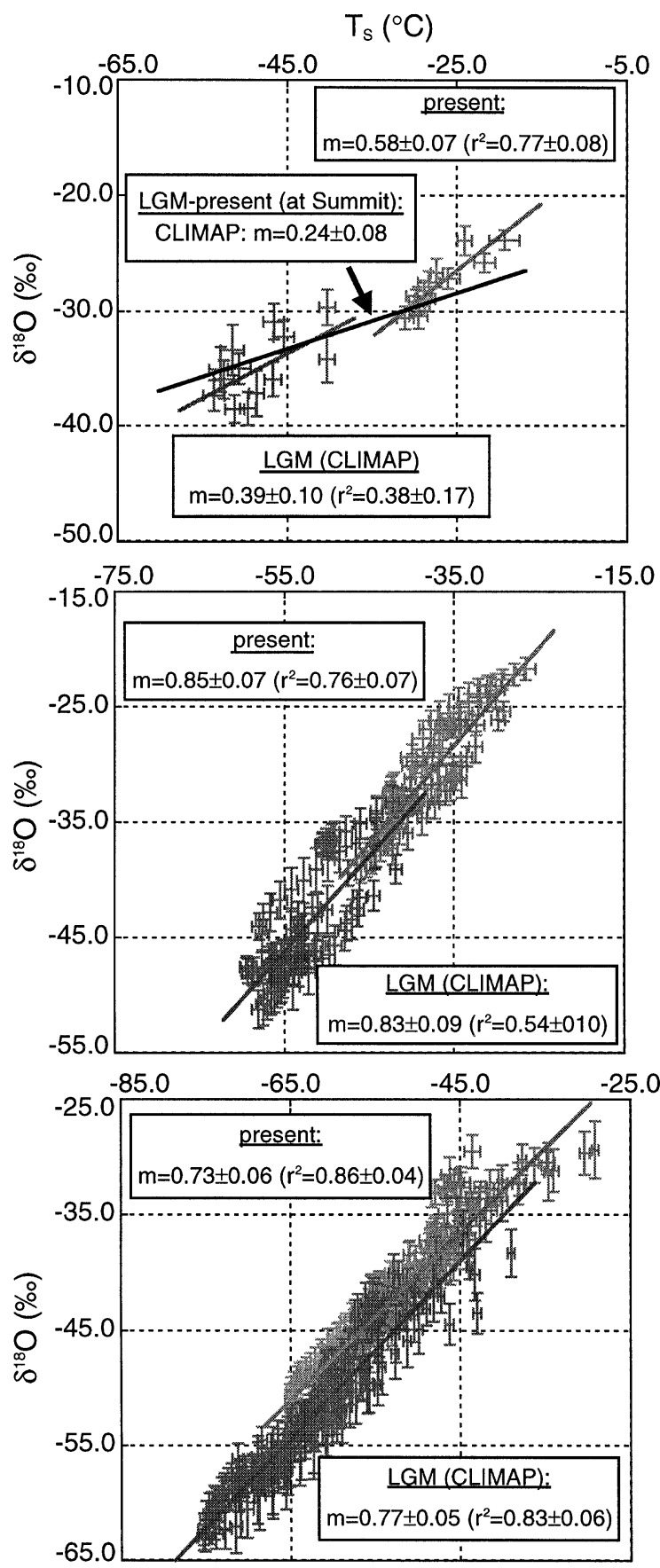

Fig. 9. Modeled mean values of $T_{\mathrm{s}}$ and $\delta^{18} \mathrm{O}$ for all grid boxes of the inner Greenland ice sheet (top), west Antarctica (center) and east Antarctica (bottom) for the present climate (light grey) and for the LGM climate (dark grey). Both present and LGM spatial $\delta^{18} \mathrm{O}-T_{\mathrm{s}}$-relations are plotted (grey lines) and the calculated spatial slopes are given in the text boxes. The temporal $\delta^{18} \mathrm{O}-T_{\mathrm{s}}$-relation of the model grid box enclosing Summit, Greenland, between LGM and present climate is also shown in the upper plot (black line).

Tellus 53B (2001), 1 
values are seen in autumn/winter and smaller values in late spring/early summer. Water from the tropical Atlantic shows no pronounced seasonality at all. Hence, we find in our simulation that the weak seasonality of the modeled total precipitation for the present climate is based on several strong seasonal signals phase-shifted against each other. While in winter (DJF) season about $77 \%$ of the Summit precipitation origins from the polar seas and the Atlantic, it is only $35 \%$ in summer (JJA) season. On the opposite, $42 \%$ of the summer precipitation stems from North America and Eurasia but only $6 \%$ of the winter precipitation. Very similar results of the seasonal variances of water from different source regions transported to Greenland were found in a tagging experiment with the GISS GCM (Armengaud et al., 1998). The analysis of simulated seasonal precipitation values for the LGM climate shows that the most significant changes are seen in the seasonal cycle of water from polar seas and the north Atlantic. Under the LGM climate, water from these source regions is no longer transported to Greenland during autumn and winter, but during summer season. Analyses of the mean geopotential height at $500 \mathrm{hPa}$ show that the shift in the seasonality of glacial precipitation can be attributed to an increased mean flow from northerly directions over central Greenland and more zonal flow over the north Atlantic and Europe. The advected air mass is substantially colder and dryer, and thus responsible for the very low precipitation in central Greenland in LGM winter.

Antarctica. For most areas of Antarctica, a clear seasonal cycle in precipitation is not observed for the present-day climate simulation (Fig. 7). Only at the eastern border of the Ross Ice Shelf slightly more austral summer than winter precipitation is seen. Our model results are in good agreement with findings of Van Lipzig (1999) using a high resolution regional climate model (RACMO) for the decade 1980-1989 with lateral boundary conditions relaxed to re-analyses from the European Center for Medium-Range Weather Forecasts (ECMWF). On the contrary, Cullather et al. (1998) report a unimodal seasonal cycle (with higher precipitation values in austral winter) for the coastal area and interior of west Antarctica. Observation data from South Pole and Vostok show also slightly higher precipitation values in austral winter (Bromwich, 1988). Compared to the present climate, the ECHAM-4 LGM simulation shows an increased seasonal cycle of precipitation in the interior east Antarctica and in Queen Maud Land. The relative difference of austral summer minus winter snow is in the range of $+10 \%$ to $+25 \%$ of the annual mean values (Fig. 7). In contrast to Greenland, changes of the seasonal distribution of precipitation are much smaller for Antarctica in the LGM climate simulation. Therefore, spatial $\delta^{18} \mathrm{O}-T_{\mathrm{s}}$-relations for present and LGM climate have very similar slopes in west or east Antarctica (Fig. 9), which are in agreement with present-day observations (Giovinetto and Zwally, 1997). Modeled temporal $\delta^{18} \mathrm{O}-T_{\mathrm{s}}$-relations on the Antarctic ice sheet have a slightly steeper slope than the spatial relations (e.g., mean temporal slope of all east Antarctica grid boxes: $m=1.06 \pm 0.11$ ). But because of the general model deficit to simulate correct low $\delta^{18} \mathrm{O}$ values in Antarctica, the significance of these small deviations between temporal and spatial slopes remains unclear. In general, the analysis of the seaonal cycle of precipitation indicates that glacial $\delta$-values from Antarctica might be a more reliable proxy for mean surface temperatures than the isotope data retrieved from Greenland ice cores. The use of cooler tropical SSTs instead of CLIMAP data does not change these findings.

\section{Conclusions}

In this article, we used an AGCM which included both stable water isotopes and the possibility to identify source regions of water vapor in precipitation to study the climate of Greenland and Antarctica for both present and the LGM climate. Simulated precipitation values on Greenland agree quite well with present-day observations. Model results suggest that the tropical and subtropical Atlantic is the dominant source region of Greenland's precipitation but that water from several different ocean and continental areas contribute together about half of the total precipitation amount falling in the Summit region. Water from these additional sources has an isotopic signature, which differs significantly from the mean isotopic composition of the precipitation, and the relative strengths of these additional sources vary with season. For the present-day climate of Antarctica, the most dominant water vapor 
sources are the surrounding oceans, but no land surfaces. Like for Greenland, water transported to Antarctica stems not from a single source region but is a mixture of coastal and far-distanced evaporation regimes. The influence of the southern Atlantic is bound to a wedge-shaped region between $0^{\circ}-100^{\circ} \mathrm{E}$ on the Antarctic ice sheet, while other regions are more influenced by the southern Indopacific. The latter is for example of some importance for the two new deep drilling sites of the European Project of Ice Coring in Antarctica (EPICA), one in Dronning Maud Land (probably near $\left.1^{\circ} \mathrm{E}\right)$ and one at Dome Concordia $\left(124^{\circ} \mathrm{E}\right)$.

Simulations of the last glacial maximum climate show decreased precipitation amounts in both polar regions but the relative contribution of different vapor sources is comparable to present values if CLIMAP SSTs are applied as a boundary condition for the LGM simulation. A sensitivity study with cooler tropical SSTs and a partly warmer north Atlantic results in an enhanced contribution of coastal waters transported to both Greenland and Antarctica. An increased seasonality in the annual precipitation cycle is observed for most regions of Greenland during the LGM, but not for Antarctica. As a direct consequence, the water isotope signal of Antarctic ice cores seems to be a surface temperature proxy less biased by seasonality of the precipitation than isotope data from Greenland ice cores.

But all performed ECHAM-4 simulations under LGM boundary conditions (either CLIMAP or cooler tropical SSTs) fail to reproduce the simultaneous decrease of both $\delta^{18} \mathrm{O}$ and the deuterium excess $d$, as it is measured in the GRIP and Vostok ice cores. Analyses of the isotopic signature of water from different source areas transported to the ice sheets reveal a relation between $\delta^{18} \mathrm{O}$ and $d$ similar to a simple Rayleigh-type model. A decreased $\delta^{18} \mathrm{O}$ signal in precipitation is always related to an increased deuterium excess signal, and vice versa. Thus, the reason for this mismatch between LGM model results and glacial ice core data remains unclear.

\section{Acknowledgements}

We are very grateful to the constructive comments and criticisms of Hubertus Fischer, Gilles Delaygue and Jean Jouzel. This study was supported by the European Community (ENV4-CT95-0130). Computing facilities were provided by the German Climate Computing Center (DKRZ) in Hamburg.

\section{REFERENCES}

Aristarain, A. J., Jouzel, J. and Pourchet, M. 1986. Past Antarctic Peninsula climate (1850-1980) from an ice isotope record. Clim. Change 8, 69-86.

Armengaud, A., Koster, R. D., Jouzel, J. and Ciais, P. 1998. Deuterium excess in Greenland snow - analysis with simple and complex models. J. Geophys. Res. $\mathbf{1 0 3}$ 8947-8953

Barnola, J. M., Raynaud, D., Korotkevich, Y. S. and Lorius, C. 1987. Vostok ice core provides 160,000-year record of atmospheric $\mathrm{CO}_{2}$. Nature 329, 408-414.

Beer, J., Siegenthaler, U., Bonani, G., Finkel, R. C., Oeschger, H., Suter, M. and Wölfli, W. 1988. Information on past solar activity and geomagnetism from ${ }^{10} \mathrm{Be}$ in the Camp Century ice core. Nature 331, 675-679.

Berger, A. L. 1978. Long-term variations of daily insolation and Quaternary climatic changes. Journal of Atmospheric Science 35, 2362-2367.

Broecker, W. S. 1996. Glacial climate in the tropics. Science 272, 1902-1904.

Bromwich, D. H. 1988. Snowfall in high southern latitudes. Rev. Geophys. 26, 149-168.

Bromwich, D. H., Robasky, F. M., Keen, R. A. and
Bolzan, J. F. 1993. Modeled variations of precipitation over Greenland ice sheet. J. Clim. 6, 1253-1268.

Charles, C. D., Rind, D. H., Jouzel, J., Koster, R. D. and Fairbanks, R. G. 1994. Glacial-interglacial changes in moisture sources for Greenland: influences on the ice core record of climate. Science 263, 508-511.

Ciais, P., White, J. W. C., Jouzel, J. and Petit, J. R. 1995. The origin of present-day Antarctic precipitation from surface snow deuterium excess data. J. Geophys. Res. 100, 18,917-18,927.

CLIMAP Project Members 1981. Seasonal reconstruction of the Earth surface at the last glacial maximum. Geol. Soc. Am. Map and Chart. Ser. MC-36, Boulder, Colorado.

Cuffey, K. M. and Clow, G. D. 1997. Temperature, accumulation, and ice sheet elevation in cenral Greenland through the last deglacial transition. J. Geophys. Res. 102, 26,383-26,396.

Cuffey, K. M., Clow, G. D., Alley, R. B., Stuiver, M., Waddington, E. D. and Saltus, R. W. 1995. Large Arctic temperature change at the Wisconsin-holocene glacial transition. Science 270, 455-458.

Cullather, R. I., Bromwich, D. H. and Vanwoert, M. L.

Tellus 53B (2001), 1 
1998. Spatial and temporal variability of Antarctic precipitation from atmospheric methods. J. Clim. 11 334-367.

Dahe, Q., Petit, J. R., Jouzel, J. and Stievenard, M. 1994 Distribution of stable isotopes in surface snow along the route of the 1990 International Trans-Antarctica expedition. J. Glaciol. 40, 107-118.

Dahl-Jensen, D., Mosegaard, K., Gundestrup, N. S. Clow, G. D., Johnsen, S. J., Hansen, A. W. and Balling, N. 1998. Past temperature directly from the Greenland ice sheet. Science 282, 268-271.

Dansgaard, W. 1964. Stable isotopes in precipitation. Tellus 16, 436-468

Dansgaard, W., Johnsen, S. J., Clausen, H. B., DahlJensen, D., Gundestrup, N. S., Hammer, C. U., Hvidberg, C. S., Steffensen, J. P., Sveinbjörnsdottir, A. E., Jouzel, J. and Bond, G. 1993. Evidence for general instability of past climate from a $250-\mathrm{kyr}$ ice-core record. Nature 364, 218-220.

Delaygue, G., Masson, V., Jouzel, J., Koster, R. D. and Healy, R. J. 2000. The origin of Antarctic precipitation a modelling approach. Tellus 52B, 19-36.

Giovinetto, M. B. and Zwally, H. J. 1997. Areal distribution of the oxygen-isotope ratio in Antarctica: an assessment based on multivariate models. Ann. Glaciol. 25, 153-158.

Grootes, P. M., Stuiver, M., White, J. W. C., Johnsen, S. J. and Jouzel, J. 1993. Comparison of oxygen isotope records from the GISP2 and GRIP Greenland ice cores. Nature 366, 552-554.

Guilderson, T. P., Fairbanks, R. G. and Rubenstone, J. L. 1994. Tropical temperature variations since 20,000 years ago: modulating interhemispheric climate change. Science 263, 663-665.

Hoffmann, G., Stievenard, M., Jouzel, J., White, J. W. C. and Johnsen, S. J. 1997. Deuterium excess record from central Greenland (modelling and observations). In: International Symposium on Isotope techniques in the study of past and current environmental changes in the hydrosphere and the atmosphere (ed. P. Murphy) I.A.E.A., Vienna.

Hoffmann, G., Werner, M. and Heimann, M. 1998. The water isotope module of the ECHAM atmospheric general circulation model - a study on time scales from days to several years. J. Geophys. Res. $\mathbf{1 0 3}$ $16,871-16,896$.

Johnsen, S. J., Dahl-Jensen, D., Dansgaard, W. and Gundestrup, N. S. 1995. Greenland paleotemperatures derived from GRIP bore hole temperature and ice core isotope profiles. Tellus 47B, 424-629.

Johnsen, S. J., Dansgaard, W. and White, J. W. C. 1989. The origin of Arctic precipitation under present and glacial conditions. Tellus 41B, 452-468.

Joussaume, J., Sadourny, R. and Jouzel, J. 1984. A general circulation model of water isotope cycles in the atmosphere. Nature 311, 24-29.

Jouzel, J. 1999. Calibrating the isotopic paleothermometer. Science 286, 910-911.

Jouzel, J., Alley, R. B., Cuffey, K. M., Dansgaard, W.,
Grootes, P. M., Hoffmann, G., Johnsen, S. J., Koster, R. D., Peel, D., Shuman, C. A., Stievenard, M., Stuiver, M. and White, J. W. C. 1997. Validity of the temperature reconstruction from water isotopes in ice cores. J. Geophys. Res. 102, 26,471.

Jouzel, J., Lorius, C., Petit, J. R., Genthon, C., Barkov, N. I., Kotlyakov, V. M. and Petrov, M. 1987. Vostok ice core: a continuous isotope temperature record over the last climatic cycle (160,000 years). Nature 329 , 403-408.

Kapsner, W. R., Alley, R. B., Shuman, C. A., Anandakrishnan, S. and Grootes, P. M. 1995. Dominant influence of atmospheric circulation on snow accumulation in Greenland over the past 18,000 years. Nature 373, $52-54$.

Koster, R. D., Jouzel, J., Suozzo, R. J. and Russell, G. L. 1992. Origin of July Antarctic precipitation and its influence on deuterium content: a GCM analysis. Climate Dyn. 7, 195-203.

Krinner, G., Genthon, C. and Jouzel, J. 1997. GCM analysis of local influences on ice core delta signals. Geophys. Res. Lett. 24, 2825-2828.

Lorius, C. 1989. Polar ice cores and climate. Climate and geo-sciences (ed. A. L. Berger). Kluwer Academic Publishers, 77-103.

Lorius, C., Jouzel, J., Ritz, C., Merlivat, L., Barkov, N. I. Korotkevich, Y. S. and Kotlyakov, V. M. 1985. A 150,000-year climatic record from Antarctic ice. Nature 316, 591-596.

Lorius, C., Merlivat, L., Jouzel, J. and Pourchet, M. 1979. A 30,000-yr isotope climatic record from Antarctic ice. Nature 280, 644-648.

Merlivat, L. and Jouzel, J. 1979. Global climatic interpretation of the deuterium-oxygen 18 relationship for precipitation. J. Geophys. Res. 84, 5029-5033.

Ohmura, A. and Reeh, N. 1991. New precipitation and accumulation maps for Greenland. J. Glaciol. 37, 140-148.

Peltier, W. R. 1994. Ice age paleotopography. Science 265, 195-201.

Roeckner, E., Arpe, K., Bengtsson, L., Christoph, M., Claussen, M., Dümenil, L., Esch, M., Giorgetta, M., Schlese, U. and Schulzweida, U. 1996. The atmospheric general circulation model Echam-4: model description and simulation of present-day climate. MPI-Report 218. Max-Planck-Institute for Meteorology, Hamburg.

Severinghaus, J. P., Sowers, T. A., Brook, E. J. Alley, R. B. and Bender, M. L. 1998. Timing of abrupt climate change at the end of the younger Dryas interval from thermally fractionated gases in polar ice. Nature 391, 141-146.

Stute, M., Forster, M., Frischkorn, H., Serejo, A., Clark, J. F., Schlosser, P., Broecker, W. S. and Bonani, G. 1995. Cooling of tropical Brazil (5-degrees-C) during the last glacial maximum. Science 269, 379-383.

van Lipzig, N. P. M. 1999. The surface mass balance of the Antarctic ice sheet: a study with a regional atmospheric model. PhD thesis. Faculteit Natuur- en 
Sterrenkunde, Universiteit Utrecht, Utrecht, The Netherlands.

Vimeux, F., Masson, V., Jouzel, J., Stievenard, M. and Petit, J. R. 1999. Glacial-interglacial changes in ocean surface conditions in the southern hemisphere. Nature 398, 410-413.

Webb, R. S., Rind, D. H., Lehman, S. J., Healy, R. J. and Sigman, D. 1997. Influence of ocean heat transport on the climate of the last glacial maximum. Nature $\mathbf{3 8 5}$, 695-699.

Weinelt, M., Sarntheim, M., Pflaumann, U., Schulz, H.,
Jung, S. and Erlenkeuser, H. 1996. Ice-free Nordic Seas during the last glacial maximum? Potential sites of deepwater formation. Paleoclimates 1, 283-309.

Werner, M., Mikolajewicz, U., Heimann, M. and Hoffmann, G. 2000. Borehole versus isotope temperatures on Greenland: seasonality does matter. Geophys. Res. Lett. 27, 723-726.

Yang, Q. Z., Mayewski, P. A., Twickler, M. S. and Whitlow, S. I. 1997. Major features of glaciochemistry over the last 110,000 years in the Greenland ice sheet project 2 ice core. J. Geophys. Res. 102, 23,289-23,299. 